Public Service in the Private Sector:

Private Loan Originator Participation in a Public Mortgage Program

\author{
Stephanie Moulton* \\ Assistant Professor \\ Ohio State University \\ Email: moulton.23@osu.edu \\ Phone: 614-247-8161
}

\author{
Mary K. Feeney \\ Assistant Professor \\ University of Illinois at Chicago \\ Email: mkfeeney@uic.edu \\ Phone: 312-355-4734
}

*Corresponding Author

Keywords: Public service, private sector, mortgage, loans,

This work was supported in part by a research grant from the U.S. Department of

Housing and Urban Development (EDSRG 07-08, Recipient Stephanie Moulton). 


\title{
Public Service in the Private Sector: Private Loan Originator Participation in a Public Mortgage Program
}

\begin{abstract}
In the United States, housing policies focused on assisting low-income families towards homeownership have resulted in the creation of publicly subsidized affordable mortgage programs. Private lenders and their employees (loan originators) are often the key point of contact to connect low-income borrowers to these public programs. But why would loan originators offer borrowers public loan programs, particularly when such programs provide no additional (and sometimes reduced) direct financial compensation to the private lenders and potentially increased workloads? One possible rationale, and the one investigated here, is that loan originators may be diversely motivated towards public service and the advancement of the public interest.

Though-Alhough a great deal of research focuses on public service motivation among public sector employees, few studies investigate the tendency toward public service motivation and action in the private sector. Here we draw from surveys of private lenders to test a model and hypotheses about how private lenders' associations, perceptions and values are related to voluntary participation in a government program. Our analysis highlights the importance of public associations, perceptions of government and public values in explaining the behavior of private sector employees. Our findings contribute to the literature on public service and public values and our understanding of how private organizations access government programs to advance the public good.
\end{abstract}


Public Service in the Private Sector:

Private Loan Originator Participation in a Public Mortgage Program

\section{Introduction}

A great deal of research has focused on understanding public service motivation (PSM) and public values in the public sector (Coursey and Pandey 2007; Perry 1996; Parry and Wise 1990-Scott and Pandey 2005; Bozeman 2007; Taylor 2008) including PSM among federal employees (Naff and Crum 1999), the role of public organizations in shaping PSM among public managers (Moynihan and Pandey 2007), and the ways in which public values are articulated through public managers' actions (Bozeman 2007). Additionally, research has sought to differentiate among different sources of public service motivation, distinguishing a desire to serve one's country from a desire to serve one's community, the less fortunate, or humanity generally (Brewer, Selden, and Facer 2000). While this research is important to understanding the motivations and commitments of public managers, it tells us little about public service motivation and the desire to advance public goals outside of the public sector.

Of course, private sector employees are also motivated to serve the less fortunate, their communities, and their country. While there is research investigating work motivation, work values, and ethics in the private sector (Steijn and Smulders 2004; Van der Wal et al 2008) and pro-social behavior in private organizations (Aguilera et al. 2007; Francois and Vlassopoulos 2008) But, we know very little about the ways in which private sector managers and employees pursue and engage public serving government programs and services. While research compares PSM levels among public and private employees, finding that, on average, private sector employees report significantly lower levels of PSM as compared to their public sector counterparts (Taylor 2008), there is a 
dearth of research on public service motivation and behavior among private sector employees. In fact, a number of scholars have asked whether or not PSM manifests itself differently in the nonprofit and private sectors as compared to the public sector (Brewer et al. 2000; Gabris and Simo 1995; Wittmer 1991), but to date, there is little empirical research in this area. The present analysis proposes and tests a model for understanding the role of associations, government perceptions, and shared public values in private sector participation with a public-serving government program.

If we consider Bozeman's (1987) argument that "all organizations are public" then it is important to understand the ways in which organizations outside of the government sector are engaged in public service and advancing public values and the public good. A great deal of public administration research has sought to understand the ways in which public service and public values are driving policy making, program implementation, and product delivery (Bozeman \& Bretschneider 1994; Feeney and Bozeman 2007). This research builds on the public values and public service research and seeks to understand the ways in which public values and public service are articulated through private sector work and action.

This research is driven by the research question: What factors (motivators) influence private actors to engage in public service? We answer this question by investigating private sector employees' the-motivations for public service-ameng individuals working in the private sector. In particular, we investigate the motivations behind why individuals working in private, for-profit loan originating organizations, known for their efforts to increase profits, might seek out and participate in government 
programs that aim to serve the public and the public good - with little or no gain to the private organization.

We present an analysis of data drawn from a set of loan originators in Indiana, Florida, and Ohio. These data are derived from an ongoing study of the Mortgage Revenue Bond program, evaluating the relationship between origination practices and borrower outcomes. ${ }^{1}$ We begin with a short description of the Mortgage Revenue Bond (MRB) program. Second, we propose three hypotheses that may predict private loan originator participation in the public program and a conceptual Model of Public Service in the Private Sector. Within this discussion we describe some of the literature guiding our hypotheses. Third, we describe the data and methodological approach for testing the hypotheses. We then present the results from the models. We conclude with a discussion of the results and how this research informs our understanding of public service and public values in the private sector.

\section{Mortgage Revenue Bond Lending Program}

First initiated in the 1970s by State Housing Finance Agencies, state Mortgage Revenue Bond (MRB) programs provide reduced interest rate mortgage financing for first time homebuyers with low and moderate incomes meeting program requirements. ${ }^{2}$ MRBs are tax-exempt securities issued by state or local housing finance agencies.

Because interest from MRBs is tax exempt, the bonds can be sold to investors at low

\footnotetext{
${ }^{1}$ The project, Mortgage Revenue Bond Program Analysis: Origination Practices and Borrower Outcomes in Ohio, Indiana \& Florida, is funded in part through an EDSRG Grant from the U.S. Department of Housing \& Urban Development, 2007-2008 (PI Stephanie Moulton).

${ }^{2}$ MRB subsidized mortgages are currently restricted by Congress to first time homebuyers (who have not purchased a home in the past three years), earning less than area median income, or less than 115 percent of area median income for families of three or more. Further, the price of homes to be purchased with MRBs is limited to 90 percent of the average purchase price. In 2006, the median income of borrowers assisted with MRB mortgages nationwide was $\$ 31,703$, which is 65 percent of the national median of 48,451 ; further, the average purchase price was $\$ 132,939,62$ percent of the national median purchase price of $\$ 222,000$ (NCSHA 2008).
} 
interest rates and the interest rate savings can be used to offer reduced interest rate mortgages to borrowers, typically originated by private lenders participating in the program. MRBs offer long-term mortgages at below-market rates with the goal of providing affordable homeownership to low- and middle-income first-time homebuyers.

Since its inception, the MRB program has successfully assisted more than 3.6 million lower income households, or about 100,000 new borrowers per year nationwide, making it one of the largest publicly subsidized low income homeownership initiatives. ${ }^{3}$ Many state MRB programs rely on private lenders to implement the program to qualified borrowers. Private lender participation in state MRB programs, however, is entirely voluntary. Lending institutions agreeing to participate in state MRB programs often register with the state Housing Finance Agency to become a "participating lender." Further, loan originators employed with participating lending institutions have considerable discretion in the degree to which they market (or promote) the program to potential borrowers. Thus, even within a single private lending institution, the number (and relative proportion) of MRB originations by individual loan originator varies significantly. While some might argue that private loan originators and private sector employees in general are driven primarily by profit motives, there is no direct, universal profit motive for participation in the MRB program. In fact, loan originators are typically paid, at least in part, on loan amount or interest rate of the mortgage and are thus likely to receive less compensation for MRB mortgages than other types of higher loan amounts and higher interest rate mortgages. ${ }^{4}$

\footnotetext{
${ }^{3}$ National statistics on the MRB program are from the National Council of State Housing Finance Agencies, obtained online at www.ncshfa.org.

${ }^{4}$ Loan originators are often paid, at least in part, on commission. This commission may be based on a percentage of the total loan amount and/or a factor based on the fees and interest charged on the mortgage.
} 
Understanding this individual discretion- the factors that motivate private sector loan originators to participate more actively in the public MRB program is important not only to understanding and increasing participation in the MRB program specifically, but in understanding private actor participation in public programs generally. We can think of numerous opportunities for private sector enrollment and participation in public programs or initiatives, which may depend more or less on the discretion of individual employees within the private organizations. In the next section we explore theoretical rationales for public service among private sector employees.

\section{Mechanisms of Public Program Participation in Mortgage Lending}

We start with the question: Why do some private originating lenders more actively participate in the MRB program than others? Drawing from previous research, we identify three levels, or modalities, of potential influence; that may affect the degree of loan originator participation: geographic, institutional, and individual. While it is the individual level that is of primary interest in this paper, it is necessary to consider (and control for) influence at the other two levels.

First, and most simply, geographic differences (at the local or state level) may directly influence the pool of available borrowers eligible to participate in the MRB program, thereby indirectly affecting the degree of a particular loan originator's participation in the program. Loan originators operating in areas with a higher concentration of low and moderate income borrowers may originate a larger proportion of MRB mortgages. Additionally, loan originators operating in areas with differing rates of homeownership and differing ages of housing stock may be more (or less) likely to originate loans through the MRB program. Indeed, geographic differences in lending 
markets is one of the primary sets of controls included in research investigating the varying portfolio of individual lending agents (Avery, Beeson and Sniderman 1994; Bostic and Robinson 2005).

Second, different institutional structures within which loan originators are employed may provide differing incentives for private loan originators to participate in the public MRB program (to a greater or lesser degree). For example, certain lending institutions may financially compensate loan originators more (or less) for MRB mortgages, relative to other types of mortgages. This compensation incentive to loan originators is one of the primary rationales for the growth of subprime lending (Alexander et al. 2002; Ding et al. 2008). Further, some studies suggest that certain lending institutions (such as those falling under Community Reinvest Act provisions) place more (or less) emphasis on originating affordable mortgages (such as MRB mortgages) to underserved and low income borrowers (Bostic \& Robinson 2005; Ding et al. 2008; Fishbein 1992; Holyoke 2004; Immergluck 2008). It is also conceivable that some lending institutions may have a culture of working with and assisting low income borrowers. Thus, different lending institutions may have differing formal and informal policies or procedures that encourage (or discourage) loan originators from actively marketing and originating loans through the MRB program (relative to their marketing and origination of other types of mortgages).

Finally, and of primary interest in this analysis, individual originators may be differently motivated to participate in the public MRB program, regardless of the geographic climate or the incentives and priorities of the loan originator's employing organization. While this individual originator discretion has not been explored in depth in 
the housing literature ${ }^{5}$, research on the decision making of front-line workers lends insight. Specifically, research on street-level bureaucracy argues that the delivery of public services is often related to perceptions of clients and whether the service provider believes that clients are deserving of and will benefit from the service (Lipsky 1980). For example, Maynard-Moody and Musheno (2003) find that, many street-level bureaucrats behave as "citizen agents" making decisions based on individual circumstances and their "social identity," and not as agents of the state acting in response to strict rules and regulations. Just as government employees shape participation in public programs, we expect that individual loan originators may shape borrower participation in the MRB program, and thus the overall participation level of the loan originator in the MRB program. In the following section we draw from the public administration and public policy literatures to propose a conceptual model of individual (employee) public service in the private sector and hypotheses for testing that model.

\section{Individual Public Service in the Private Sector}

Taken as a whole, the degree to which a private lending institution participates in the public-MRB program may be viewed as an indication of the "publicness" of the lending institution. According to Bozeman $(1987,2007)$, publicness is the degree to which an organization is constrained or enabled by political authority. Such political authority is generally operationalized at the formal institutional level (from government), such as the percent of funds an organization receives from government, communication with government or degree of regulation from government sources (Bozeman and

\footnotetext{
${ }^{5}$ One exception is the substantial literature on discrimination in mortgage lending, that suggests lending agents (including but not limited to loan originators) may exhibit discretion in approving or denying mortgages (or in soliciting applications) based on race or ethnicity. For a review of this literature, see Ladd (1998).
} 
Bretschneider 1994; Emmert and Crow 1998; Heinrich and Fournier 2004; Scott and Falcone 1998). However, in recent conceptualizations, publicness has been enlarged defined to encompass public values more broadly (Antonsen and Jorgensen 1997; Bozeman 2007; Moulton 2009), thus expanding from strictly formal institutions of political authority to include less formal institutionalizations of public values that may influence public outcomes. Specifically, the "realized publicness" framework presented by Moulton (2009) suggests that public outcomes may be "realized" through regulative (formal structural), associative (informal networks or community ties) and culturalcognitive (individual perceptions and beliefs) institutions.

While individual loan originators employed with the same lender likely share the same regulative (structural) influences that might determine their public lending behavior, it is likely that there is associative and cultural-cognitive variation at the individual level. This individual variation can be aggregated by organization (i.e., all employees within a given organization) to predict organizational level outcomes; however, if analyzed by individual lending agent, they may help explain individual employee variation in public outcomes- such as public program participation. These associative and cultural-cognitive motivations are thus the primary focus of our analysis.

Associative: Community Ties. Associative influences are related to the relationships of individual loan originators acting in their "official" roles with other entities that do not have formal authority over the individuals, but can exhibit constraint and shape behavior through shared norms, professional networks or ties (Moulton 2009; Powell 1990; Scott 2003). Like all interorganizational actions, the decision for an employee to engage in public service, or participate in government programs, is 
embedded in a social network of ongoing personal relationships between individual actors and organizations. If governance emerges from "the values and agreed-upon processes found in social relationships" (Poppo and Zenger 2002, p. 709), then the decision for an employee to engage in a public program is critically tied to social relationships, or associations.

Private loan originators engage with a variety of actors in their "official" role as lending agents, including realtors, housing counselors, other nonprofit organizations, local government agencies, private businesses, builders and other lenders. Drawing from the literature on social networks (Burt 1992; Granovetter 1973; Uzzi 1999), there are at least two modalities by which such associations may influence lender participation in the public MRB program. First, the frequency of associations generally (or number of ties) may be associated with an increase in public service. Those loan originators with more connections to their communities, generally, may be more likely to participate in the public MRB program. Second, the types of associations (or the nature of the ties) may be associated with participation in public service. In particular, an increase in the publicness of interactions- or more frequent interaction with more public entities (relative to private entities), may increase a loan originator's participation in the public MRB program.

H1: Respondents with increased frequency of contact with community entities generally will report increased MRB program participation.

$\mathrm{H} 2$ : Respondents with increased frequency of contact with relatively more public entities will report increased MRB program participation.

Cultural Cognitive. The cultural cognitive component of organizations, shaped by individual employees, is closely related to the public service motivation (PSM) literature. While much of the PSM literature has been employed to describe the behavior of 
government employees ${ }^{6}$, Brewer and colleagues (2000) argue that, "Many people outside government have strong motives to perform meaningful public, community, and social service, and these activities are vitally important to society at large" (pg 254). Thus, studying PSM may help us to understand the ways in which motivations to serve the public can explain human behavior generally. In their assessment-of types of public service motivation, Brewer and colleagues (2000) identify four types of public service motivation- - PSM: Samaritans, Communitarians, Patriots, and Humanitarians. Here, we simplify this distinction to two primary types of public motivation- one towards government generally (and specific government programs), and the other towards the substantive values underlying specific programs (shared public values). Both are discussed in turn.

Perception of Government. Drawing from a variety of public administration and public management research, we propose that the level of participation in a government program among private sector employees will be related to the level of employees' positive perceptions of government generally, and positive perceptions of the government program, specifically. Researchers note that perceptions, whether or not they are true, realistic, and consistent, affect behavior and individual actions and relationships (Buckley and Chapman 1997; O’Connor, Bord and Fisher 1999). Public administration research has long worked to understand the ways in which citizens perceive government and the

${ }^{6}$ The-Brewer and colleagues' (2000) typology of PSM was developed using responses from a set of workers in the public sector, specifically people working in federal agencies, state government, local government, and students of government and public administration. Thus, we do not know if these types of motivations are generalizable to the private sector. However, we can speculate that there are individuals within the private firms who have tendencies toward public service. Moreover, it is reasonable to expect that some private sector workers, in this case mortgage lenders, are willing to forego financial and economic rewards to advance the interests of their community. 
effects of such perceptions on support for or participation in government initiatives and programs (see Goodsell 2004).

In addition to the importance of perceptions of government, we expect that positive (or negative) perceptions of the MRB program itself will increase (or decrease) participation in the MRB program. To the extent that loan originators view the MRB program as cumbersome or burdensome, such originators may be less likely to participate in the MRB program. According to Rosenfeld (1984) the growth of government has expanded the amount of detailed guidelines and procedures for decision-making and activities. The sum of these guidelines, procedures, forms, rules, and red-tape serve to increase the administrative burden on public agencies and programs, but also serve as a disincentive for citizens and private actors to engage in relationships with government agencies $^{7}=$ Although research on formalization, rules, and red tape indicates that formal rules and processes can have detrimental effects on organizational commitment and increase role stress and work alienation (Agarwal 1993) and decrease organizational performance (Boyne et al 2006), there is little research focused on how formalization, red tape, and other barriers discourage participation in public programs. We expect that those Those loan originators, therefore, perceiving increased hassle or burden associated with the MRB program are theswill be less likely to originate a substantial proportion of MRB mortgages. ${ }^{8}$

H3: Respondents with more positive perceptions of government will report increased MRB program participation.

\footnotetext{
${ }^{7}$ It is also important to control for a loan originator's experience with mortgage lending and with the MRB program, as experience can decrease the perceived burden of the program.

${ }^{8}$ Although research on formalization, rules, and red tape indicates that formal rules and processes can have detrimental effeets on organizational commitment and inerease role stress and work alienation (Agarwal 1993) and decrease organizational performance (Boyne et al 2006), there is little research focused on how formalization, red tape, and other barriers discourage participation in public programs.
} 
H4: Respondents with viewing the MRB program as less burdensome will report increased MRB program participation.

Shared Public Values. Public administration research has long held that civil servants and government employees have a set of values (and thus motivations) distinct from the private sector. This "public service ethic" (Buchanan 1975) has advanced a steady stream of public administration research focused on the public service motivations and values inherent in government employees. Recently, Van der Wal and colleagues (2008) observed that public and private sector employees, in general, have very different value sets. For example, when asking public and private sector workers to rank the top 10 values in their respective organizations, Van der Wal and colleagues (2008) found that public sector workers report that the top four most important values in the public sector are accountability, lawfulness, incorruptibility, and expertise and that the top four values should be accountability, effectiveness, incorruptibility, and reliability. In comparison, private sector employees report that the most important values in their organizations are ranked from one to four as profitability, accountability, reliability, and effectiveness. -Some researchers go so far as to note that public sector workers are attracted to the public sector because of their desire for intrinsic motivations and a job that values their altruistic needs (Perry and Wise 1990; Vandenabeele et al. 2006). While research indicates that many public-service minded individuals are attracted to the public sector and public sector employees, on average, have a more public service minded approach to work, there is little research investigating the ways in which shared public values, or the desire to advance the public good, are articluated in the private sector. 
Certainly, there are private sector employees who have a strong sense of altruism and a desire to serve less advantaged individuals in our society. In particular, we expect that there are individual loan originators working in the private sector who may exhibit a strong desire to help low-income buyers into affordable home ownership. Especially when we consider the strong cultural value attached to home ownership in the United States and the numerous affordable lending programs that aim to encourage home ownership, it makes sense that individuals working in private lending organizations understand the positive outcomes and public value of homeownership and the ways in which low-income buyers and communities can benefit from programs aimed to assist with access to affordable home ownership. Thus, we expect that:

H5: Respondents placing higher importance on affordable homeownership for low income borrowers will report increased MRB program participation.

\section{Model of Public Service in the Private Sector}

To appropriately test the hypotheses related to individual motivators of public service, it is necessary to account for the geographic and institutional factors that might increase participation in public service programs. Indeed, for any private organization, employee "public behavior" can be appropriately conceptualized within the context of the organization and the context of the geography within which the organization is located. Figure 1 illustrates a simple conceptual "Model of Public Service in the Private Sector", which situates the individual motivators discussed above within an institutional and geographic context. 
The Model of Public Service in the Private Sector is intended to develop a general model for understanding how individual public service operates in the private sector. This model, while tested in this case using data related to the MRB program, can be used to test for ways in which individuals in other areas of the private for-profit and nonprofit sectors might be variously motivated to participate in government services and programs.

\section{Figure 1 Conceptual Model of Individual Public Service in the Private Sector}

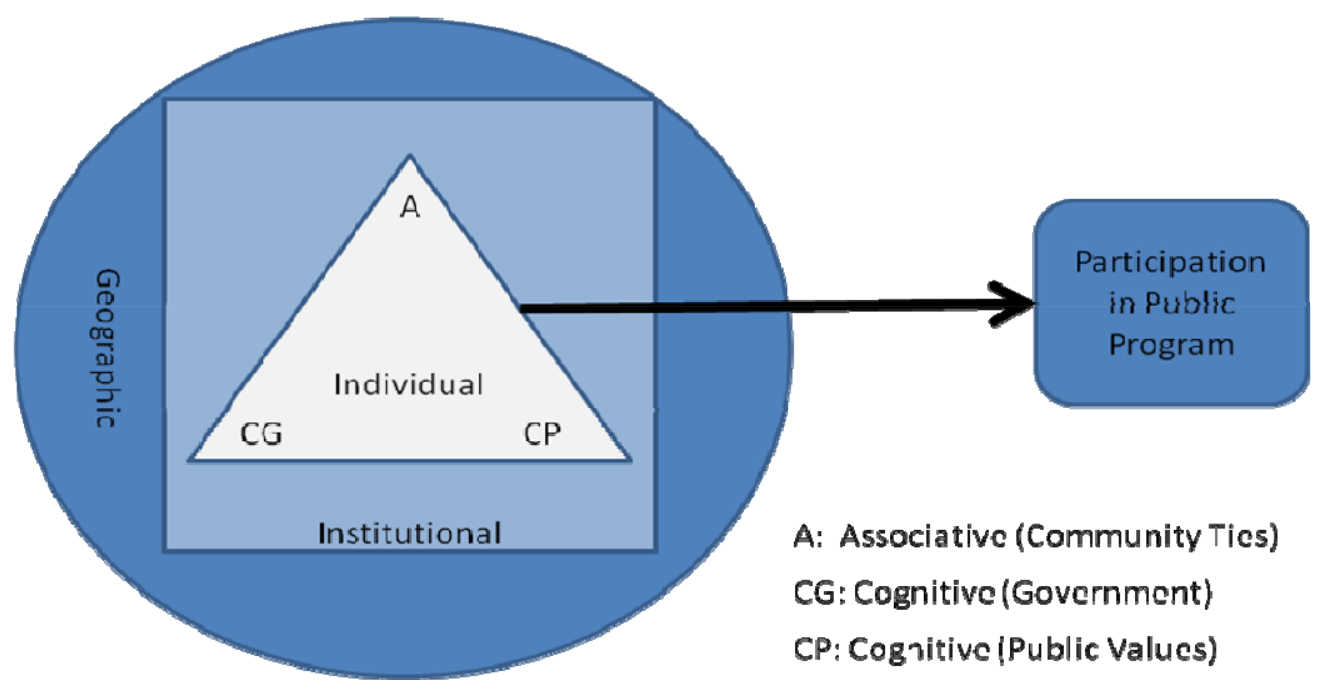

Our analysis draws on data from a case study including the entire population of lenders participating in the MRB program in three states. Although these data are not generalizable to all private mortgage lenders across states or all private organizations, this research is an ideal first step in testing the proposed hypotheses and model. By testing the Model of Public Service in the Private Sector with data from the MRB program we advance our understanding of the relative importance of associations, government perceptions and shared public values on increasing participation in this public-serving program.

\section{Research Design: Data and Models}


Data Sources. To investigate the hypothesized relationships, this analysis relies on data from private loan originators participating in the Mortgage Revenue Bond (MRB) programs in Indiana, Ohio and Florida. All lending institutions participating in the MRB program in the three states in 2008, or 264 unique institutions, were contacted by email to complete the loan originator survey electronically. For this study, the primary indicators are derived from survey responses from 610 loan officers from 139 unique lending institutions, representing a response rate of 53 percent. See Appendix A for details on the survey administration procedures and response rates by state.

While 610 loan originators responded to the survey, not all originators responded to every item on the survey, due to survey fatigue (fewer responses for indicator items appearing later in the survey). Thus, the number of responses per indicator item ranges from 463-610 responses. Table 1 includes descriptive statistics of indicator items.

In addition to survey data from loan originators, our analysis incorporates data on county level characteristics from the 2000 U.S. Census Bureau and the Bureau of Labor Statistics. In particular, the average county demographics are computed for the counties served by loan originators (originators were asked to identify the primary counties where they originate mortgages). These county average indicators serve as control variables for the overall analysis.

\section{-Table 1 Here-}

Dependent Variable. The dependent variable in this analysis assesses the degree of loan originator participation in the MRB program and is measured by the proportion of a loan originator's total lending volume that was MRB mortgages, or MRB Loan Volume. Loan originators were asked "Thinking back on the mortgages you have originated in the 
past 12 months, about what percent were MRB mortgages?" Originators were able to select from the following categories: less than 5 percent, 5 to 25 percent, 26 to 50 percent, 51 to 75 percent, or greater than 75 percent. For this analysis, because only 10 percent of respondents report that more than half of their loan volume is with the MRB program, we collapse the data into four categories, with one category created for greater than 50 percent (combining $51-75$ percent and greater than 75 percent).

Independent Variables. The primary independent variables in this analysis represent the constructs for associative and cultural cognitive influences, while controlling for institutional and geographical characteristics. Key survey questions related to the constructs provide the data for the primary independent variables (See Appendix A for key survey questions). Survey responses were first examined for multicolinearity (see correlation matrix in Appendix B). As expected, survey responses related to the culturalcognitive component, including government perceptions and public values, were highly correlated with each other. Also, survey responses related to community ties were highly correlated with each other. Thus, the two sets of correlated items were further factor analyzed using principal components factor analysis, and underlying factors for each construct were extracted to create the primary independent variables.

The cultural-cognitive factor analysis includes originator perceptions of government and shared public values. First, originator perceptions of government are measured by four survey items, one related to government in general (Public Hassle), and three specific to the public MRB program (MRB Helpful, MRB Important, MRB Hassle). Second, the alignment of loan originator values with the public values of the MRB program was measured by a series of three survey questions related to the importance of 
low income homebuyers to the lender's overall business (Low Income Borrowers), and the importance of affordable mortgage financing, measured by two survey items (Fixed Low Interest Rates and Flexible Rates for High Risk). The survey indicator, Flexible Rates for High Risk, is inversely associated with affordability, where a lender who strongly values flexible rates for higher risk borrowers places a lower value on affordable mortgage financing.

As demonstrated on tFable 2, four underlying factors (components) are extracted from the principle components factor analysis of the eight survey items, with two factors related to government perception (Low Public Factor and Low MRB Factor) and two factors related to the shard public values of the MRB program (Low Income Factor and High Cost Factor). Together, these factors explain more than 82 percent of the common variation in the initial correlation matrix. The Low Public Factor loads substantially on indicators representing the burden, or cumbersome nature of public programs (including but not limited to the MRB program), and the Low MRB Factor loads most dominantly on the hassle of the MRB program, specifically, relative to any benefit it provides. The Low Income Factor loads substantially on the importance of low income borrowers and affordable financing for low income borrowers (including but not limited to the MRB program). Finally, the High Cost Factor loads primarily on less affordable, higher cost financing to credit compromised borrowers.

-Table 2 Here-

The community ties factor analysis includes six survey items related to the frequency of lender contact with six different entities: Nonprofit Organizations, Housing Counselors, Local Government, Private Builders, Other Lenders and Other Private 
Businesses. ${ }^{9}$ Again, the high multicolinearity of these indicator responses (see Appendix B) necessitates the need for principal components factor analysis to extract the underlying factor(s) that explain the constructs. Two underlying factors are extracted to measure the overall external contact frequency of the loan originators with any entity (External Contact Factor) and the relative degree of contact with more public entities (Low Public Contact Factor). As demonstrated by the loadings on the Low Public Contact Factor (tFable 3), local government entities, nonprofit organizations and housing counselors (typically employed by either nonprofit organizations or government agencies) are considered to have a higher degree of publicness than private builders, other lenders, or other private businesses. Together, the External Contact Factor and the Low Public Contact Factor explain 64.6 percent of the common variation in the initial correlation matrix of the community ties survey items.

-Table 3 Here-

While motivational differences are the primary independent variables of interest, we also include the educational level (College Degree), community experience (Time Community), and mortgage lending experience (Time Job) of loan officers which may predict participation in the MRB program. ${ }^{10}$ Additionally, because it is essential to control the institutional structure within which the originating lender operates we take two approaches. First, we control directly for potential observable variations between institutional structures, including whether or not the lending institution is a depository

\footnotetext{
${ }^{9}$ Frequency of contact choices include: never, less than yearly, yearly, monthly, weekly and daily.

${ }^{10}$ The variable College Degree is a dummy variable indicating whether or not the respondent completed a four year degree program. The variables Time Community and Self MRB are measured by the number of years that the respondent reported living in the community and originating MRB mortgages, respectively. Responses were provided in 13 categories, ranging from less than 1 year to more than 20 years, with two years for each category in between. The variable Time Job is measured by the number of years that the respondent reported being employed in their current position in 22 categories, ranging from less than 6 months to more than 20 years with one year for each category in between.
} 
institution (Bank) and thus subject to regulations under the Community Reinvestment Act, as well as the size of the lending institution measured by the number of total lending institution branches nationwide (Lender Large $=$ more than one hundred branches nationwide; Lender Small=fewer than ten branches nationwide). ${ }^{11}$ While the benefit of this approach is the ability to discern the varying impact of distinct institutional variables, there is potential that some important components of institutional structure may be overlooked or unmeasured, such as the varying financial compensation to loan originators for various loan types. Second, to account for institutional variation we estimate a fixed effects model that holds institutional differences constant. ${ }^{12}$

Finally, geographical characteristics may influence the degree of participation in the MRB program. The lender survey asked loan originators to select the primary counties in which they originate mortgages. Each county was matched with key characteristics, including the median income of the county (County Income), the average age of the housing stock in the county (County Housing Age), the homeownership rate in the county (County HO Rate), and the county unemployment rate as of 2008 (County Unemployment). ${ }^{13} \mathrm{We}$ developed control variables to describe the loan originators' geographic service areas by averaging the county characteristics across the counties identified by the lender. Finally, we include dummy variables to identify the state in which the loan originator operates (Indiana, Ohio, and Florida).

\footnotetext{
${ }^{11}$ Lending institution size is typically measured by the asset size of depository lending institutions. However, this asset information is not publicly available for non-bank entities (mortgage companies and brokers), and is further not comparable between bank and non-bank entities. Therefore, the number of offices is included here as a proxy for lending institution size.

${ }^{12}$ There are several statistical strategies one can use to estimate fixed effects models. One of the more traditional strategies is to simply include a series of dummy variables representing the lending institutions for which loan originators are employed (with an excluded reference category).

${ }^{13}$ County Income, County Housing Age and County HO Rate are from the 2000 U.S. Census Data. County Unemployment is from the U.S. Bureau of Labor Statistics for 2008.
} 
Statistical Methodology. The primary dependent variable, MRB Loan Volume, is a categorical variable with ordered, mutually exclusive outcome categories. To account for the categorical, polytomous nature of the dependent variable, we employ multinomial logit regression analysis (MNL). The use of the multinomial logit model is appropriate for a categorical dependent variable, where the sum of the probabilities of all possible outcomes is equal to one. The primary disadvantage of the multinomial logit is the assumption that the alternatives are independent, or the Independence from Irrelevant Alternatives (IIA) assumption (Long 1997). However, a Hausmann test of the primary model confirms that this analysis does not violate the IIA assumption, and thus the MNL model can be used appropriately.

In addition to estimating an MNL model with the model independent variables, we include dummy variables for each lending institutions from which responses from five or more loan originators are included in the analysis (19 of 99 lending institutions included in the analysis). The inclusion of these variables acts as a "fixed effects" estimator at the level of the lending institution, holding constant unmeasured variation at the institutional level that may drive MRB Loan Volume. The direct inclusion of dummy variables is preferred to estimating a fixed effects model by lending institution, as there are many lending institutions for which there is only one loan originator respondent included in the analysis (and these observations would be discarded in a fixed effects model). To further ensure robust estimates and account for potential grouping or loan originator responses by unmeasured characteristics of lending institutions, the standard errors are adjusted for clustering by lending institution using STATA's cluster command (see Long and Freese 2006). 
There are limitations to interpreting the coefficients directly from an MNL model, as the coefficients themselves are not directly interpretable and are only valid in comparison to the excluded base category. To address these limitations, we provide the exponentiated beta coefficients for each of the model estimates, interpreted as a standard $\log$ odds ratio as the change in probability of being in the category of interest versus the base category for a one unit change in the independent variable. Second, and perhaps more helpful, we estimate predicted probabilities for the primary independent variables, or the probability of being in the category of interest for a specified change in the given independent variable, holding all other variables at their respective mean or modal values.

\section{Results}

Table 4A includes the results from the MNL model predicting MRB Loan Volume and Ttable 4B includes the predicted probabilities from the MNL model for the key independent variables. The complete results from the MNL model including the coefficients for the lender dummy control variables are included in Appendix C. The complete model explains roughly 23 percent of the total variation in MRB Loan Volume, at $\mathrm{p}<.01$. First, we present the results as related to the five hypotheses. Second, we present the results related to the institutional characteristics and control variables in the model.

-Tables 4A and 4B Here-

Associative: Community Ties. The first two hypotheses propose that respondents with increased frequency of contact with the community generally, and public institutions specifically, will report increased MRB participation. The model presented in țable 4A indicates that there is no significant relationship between external contact (External 
Contact Factor), and MRB lending volume. However, the publicness of a loan originator's contacts (Low Public Contact Factor), as evidenced by less contact with housing counselors, nonprofit organizations, or local government, is significantly associated with a decrease in the probability of providing high or very high MRB Loan Volume. Based on the predicted probabilities on $\underline{\mathrm{t} F \mathrm{able}} \mathrm{4 \textrm {B }}$, a one unit increase in the Low Public Contact Factor is associated with an 11 percent increase in the probability of a loan originator originating a moderate portion of MRB loans (5-25\%), and an eight percent decrease in the probability of a loan originator originating a high portion of MRB loans (more than $50 \%$ of total loan volume). Thus, while we do not find support for hypothesis $\mathrm{H} 1$, we find partial support for hypothesis $\mathrm{H} 2$ that loan originators who have increased contact with organizations that are "more public" are more likely to participate in the MRB program. This finding points to the importance of understanding the publicness of ties, not just ties between private sector actors and public programs.

Cultural Cognitive: Government Perceptions. We find strong support for the third and fourth hypotheses; that private sector loan originators with more positive perceptions of government generally and the MRB program specifically will report increased MRB program participation. Our models operationalized government perceptions in two ways: (1) the perception of government as burdensome or less efficient and (2) the perception of the MRB program as more of a hassle than a benefit. We find that a Low Public Factor, or the view that government is burdensome and inefficient, is significantly associated with the probability of originating a low volume of MRB loans, and is negatively associated with the probability of high or very high proportion of MRB loans. Specifically, a one unit increase in the Low Public Factor is associated with a 12 percent 
increase in the probability that a loan originator will originate a low proportion of MRB mortgages. Similarly, a one unit increase in the factor for low public is related to a 12 percent decrease in the probability that a loan originator will originate a very high proportion of MRB mortgages (see Ttable 4B). Additionally, the Low MRB Factor, or the perception of the MRB program as more of a hassle than a benefit, is significantly associated with an increase in the probability of originating a low proportion of MRB mortgages. Likewise, the Low MRB Factor is related to a decrease in the probability of originating a high or very high proportion of MRB mortgages. Thus, loan originators' perceptions of government generally $(\mathrm{H} 3)$ and the MRB program in particular $(\mathrm{H} 4)$ are significantly related to the degree of lender participation in the MRB program.

Cultural Cognitive: Shared Public Values. We find partial support for our fifth hypothesis-- that loan originators with increased desires to serve the public good (originate affordable mortgages to low income borrowers) report increased MRB participation. We operationalized the measure of the individual's desire to serve the public with two measures: Low Income Factor, the perceived importance of low income borrowers and affordable reduced rate financing, and High Cost Factor, the importance of providing high cost mortgages to credit compromised borrowers. As expected, the Low Income Factor is significantly associated with a decrease in a low proportion of MRB mortgages and an increase in a high or very high proportion of MRB mortgages. Loan originators who believe that it is important to provide affordable mortgages to low income borrowers are more likely to originate a higher proportion of MRB mortgages. 
The variable High Cost Factor is not statistically significant in the MNL model and does not provide evidence for our fifth hypothesis..$^{-14}$

We now turn to the remaining control variables in the model. First, the institutional characteristic of whether or not a loan originator is employed with a depository institution (subject to additional regulation, such as the CRA), or Bank, is not significantly related to MRB loan volume. Lender size is slightly positively related to low MRB Loan Volume. Small lenders and larger lenders are both slightly more likely than medium sized lenders to report a low MRB Loan Volume as compared to a medium volume. However, lender size is not significantly related to reporting high or very high MRB Loan Volume. This may suggest that there are nuances in the institutional structure and incentives of individual lending institutions that are not captured by the regulatory structure or size of the lending institution. Further investigation into these structural differences is warranted, but is not the primary focus of the present analysis. For this analysis, we are content to control for these differences (through the inclusion of the dummy variables). As shown in Appendix C, many of these fixed effects controls for lending institution are significantly associated with the MRB loan volume of originators.

The control variables describing the geographic location of the loan originator's service area were relatively insignificant predictors of MRB Loan Volume. An increase in the average income of counties served by a loan originator (County Income) is negatively associated with the probability that a loan originator will originate very few MRB mortgages. On the other hand, an increase in the average unemployment rate of the counties served is associated with a decrease in the probability that a loan originator will

\footnotetext{
${ }^{14}$ High Cost Factor is significant in alternative specifications based on logistic regression predicting a decrease in the probability of reporting very high participation in MRB.
} 
provide a high proportion of MRB mortgages (relative to the base category, or average proportion of 5-25\%).

Finally, some of the individual characteristics of loan originators (control variables) are related to the volume of reported MRB mortgages. For example, loan originators with a college degree as compared to those without a college degree are less likely to have a low volume of MRB mortgages. The three variables for lender experience: Time Community, Time Job, and Time MRB, are highly collinear with each other, and thus statistical relationships should be interpreted cautiously. For example, after controlling for the time working with the lending institution (Time Job) and the time providing MRB mortgages (Time MRB), the number of years that a loan originator has lived in the community (Time Community) is negatively related to reporting high MRB volume, but time in the community is not significantly related to reporting low or very high MRB volume. Meanwhile after controlling for the time in the community and time working with the lending institution, the amount of time that the originator has worked with the MRB program (Time MRB) is positively related to reporting a high proportion of MRB mortgages. At the same time, the time on the job (Time Job) after controlling for time working with the MRB program (Time MRB) is negatively associated with a very high proportion of MRB loans. This makes sense, as a loan originator's volume of lending through the MRB program is positively related to their experience with the MRB program, both in number of years directly and relative to their total time on the job and time living in the community where they originate loans.

\section{Concluding Discussion}


Despite its limitations, $\underline{T}$ this research significantly extends the our understanding of public service in the private sector. This analysis finds that in addition to geographic and institutional characteristics, individual characteristics of private loan officers are significantly related to their degree of participation in the MRB program. Much like "street level bureaucrats", private sector employees on the front line may be motivated to and use individual discretion to shape the outcomes of public programs. Specifically, among private loan officers, affinity for government, community ties, and public values are significantly related to the degree of participation in a public serving government program. Thus, the public service behavior of these private actors is not completely determined by their geography or institutional structure; they have discretion to influence public outcomes and the public good.

Second, this analysis lends empirical support for the distinct concepts in our Model of Public Service in the Private Sector. In relation to the Cultural-Cognitive component, we find that perceptions of government and government programs are distinct constructs from shared public values. While government perceptions predict participation in the government program generally, shared public values predict a substantial increase in participation in the public program. Thus, perceptions of government may be a necessary condition to induce participation, but may not be a sufficient condition to explain substantial participation (where shared public values play a role).

This analysis also finds that Associations (community ties) are comprised of distinct concepts that differently contribute to public program participation. The analysis demonstrates that the publicness of a private lender's associations - not just the number of 
associations- influence participation in the public program. Specifically, the number of community ties affects participation, but ties to public serving organizations (government and not-for profit) predict very high participation in the program.

In conclusion, the findings from this analysis extend research demonstrating that front line individuals in public organizations have the potential to shape outcomes (Lipsky 1980; Maynard-Moody and Musheno (2003). Indeed, front line individuals in private organizations engaged in public programs may also shape outcomes, based on their individual public associations, perceptions, and shared public values. This suggests that when public programs are implemented by private actors, it is important to consider the individuals who will be implementing the programs and their varying motivations towards public service. This exploratery-analysis offers an initial, testable Model of Public Service in the Private Sector that incorporates geographical, institutional, and individual factors to predict public service participation.

Because this research is exploratory, iIt is important to point out its-the limitations of this work. First, we test our conceptual model using data from a single government program, limiting the generalizability of the findings. HoweverThat said, the data are drawn from three states and all counties within those states providing. Thus, the-variation across state and within state addsand adding -robustness to the models. Nonetheless, this research and the analysis have limited generalizability to other states or to other public programs. Second, this analysis employs responses to unique survey questions to measure the public serving motivation of private employees. The survey responses used to measure the constructs of associative ties, government perceptions, and shared public values are unique to this analysis. While principal components factor analysis helps 
improve the measurement of the constructs (by developing the indicators from a series of related survey items rather than one survey item), further testing in other contexts with additional data is necessary to ensure construct validity. Finally, the

Our conceptual Model of Public Service in the Private Sector presented here-is enly-the initial stage of a more fully developed model. We hope that future research further analyses could incorporate direct and indirect institutional predictors (structural and economic) of public serviceFor example, rather than simply controlling for institutional factors (through fixed effects), further analyses could ineorporate direct and indirect institutional predictors (structural and economic) of public service. The-Modeling the interactions between individual level and institutional level predictors could be modeled to provide additional explanatory power. 
Table 1: Descriptive Statistics

\begin{tabular}{|c|c|c|c|c|c|}
\hline Variable Name & $N$ & Mean & $S D$ & Min & Max \\
\hline \multicolumn{6}{|l|}{ Dependent Variables } \\
\hline MRB Loan Volume & 565 & 2.080 & 1.055 & 1 & 5 \\
\hline Less than $5 \%$ & 565 & 0.327 & & 0 & 1 \\
\hline $5-25 \%$ & 565 & 0.409 & & 0 & 1 \\
\hline More than $25 \%$ & 565 & 0.264 & & 0 & 1 \\
\hline More than $50 \%$ & 565 & 0.096 & & 0 & 1 \\
\hline \multicolumn{6}{|l|}{ Control Variables } \\
\hline County Income & 601 & 10.654 & 0.132 & 10.215 & 11.171 \\
\hline County Housing Age & 601 & 26.522 & 8.273 & 11 & 48.5 \\
\hline County Unemployment & 601 & 6.107 & 0.875 & 3.8 & 8.75 \\
\hline County HO Rate & 601 & 0.719 & 0.049 & 0.549 & 0.840 \\
\hline Bank & 609 & 0.484 & 0.500 & 0 & 1 \\
\hline Lender Small & 603 & 0.171 & 0.377 & 0 & 1 \\
\hline Lender Large & 603 & 0.567 & 0.496 & 0 & 1 \\
\hline Indiana & 610 & 0.233 & 0.423 & 0 & 1 \\
\hline Ohio & 610 & 0.359 & 0.480 & 0 & 1 \\
\hline College Degree & 519 & 0.626 & 0.484 & 0 & 1 \\
\hline Time Community & 470 & 10.032 & 3.841 & 1 & 13 \\
\hline Time Job & 609 & 6.415 & 5.662 & 0 & 21 \\
\hline Time MRB & 466 & 5.833 & 3.404 & 1 & 13 \\
\hline \multicolumn{6}{|l|}{ Perception of Government } \\
\hline Public Hassle & 464 & 3.080 & 1.176 & 1 & 5 \\
\hline MRB Helpful & 464 & 3.845 & 1.282 & 1 & 5 \\
\hline MRB Important & 464 & 4.442 & 0.870 & 1 & 5 \\
\hline MRB Hassle & 463 & 1.998 & 1.048 & 1 & 5 \\
\hline \multicolumn{6}{|l|}{ Shared Public Values } \\
\hline Low Income Borrowers & 466 & 4.077 & 0.936 & 1 & 5 \\
\hline Fixed Low Interest Rates & 466 & 4.575 & 0.773 & 1 & 5 \\
\hline Flexible Rates for High Risk & 464 & 3.950 & 1.151 & 1 & 5 \\
\hline \multicolumn{6}{|l|}{ Community Ties } \\
\hline Nonprofit Organizations & 519 & 3.040 & 1.495 & 1 & 6 \\
\hline Housing Organizations & 520 & 2.817 & 1.527 & 1 & 6 \\
\hline Local Government & 521 & 2.971 & 1.538 & 1 & 6 \\
\hline Private Builders & 520 & 3.802 & 1.594 & 1 & 6 \\
\hline Other Lenders & 520 & 3.521 & 1.583 & 1 & 6 \\
\hline Other Private Businesses & 517 & 3.244 & 1.746 & 1 & 6 \\
\hline
\end{tabular}


Table 2: Rotated Factor Loadings for Cultural-Cognitive Factors

\begin{tabular}{rcccc}
\hline Scale Item & $\begin{array}{c}\text { Low Income } \\
\text { Factor }\end{array}$ & $\begin{array}{c}\text { Low Public } \\
\text { Factor }\end{array}$ & $\begin{array}{c}\text { Low MRB } \\
\text { Factor }\end{array}$ & $\begin{array}{c}\text { High Cost } \\
\text { Factor }\end{array}$ \\
\hline Government Perception & & & & \\
Public Hassle & 0.170 & $\mathbf{0 . 8 3 4}$ & 0.263 & -0.046 \\
MRB Helpful & 0.366 & $-\mathbf{0 . 7 9 6}$ & -0.105 & 0.059 \\
MRB Important & $\mathbf{0 . 7 7 0}$ & -0.105 & -0.343 & 0.134 \\
MRB Hassle & -0.099 & 0.202 & $\mathbf{0 . 9 4 5}$ & -0.039 \\
Shared Public Values & & & & \\
Low Income Borrowers & $\mathbf{0 . 8 0 1}$ & -0.138 & 0.066 & 0.221 \\
Fixed Low Interest Rates & $\mathbf{0 . 8 1 9}$ & 0.057 & -0.068 & 0.279 \\
Flexible Rates for High Risk & 0.224 & -0.054 & -0.041 & $\mathbf{0 . 9 6 8}$ \\
Eigenvalue & 2.128 & 1.407 & 1.101 & 1.089 \\
Percent of Variance & $30.4 \%$ & $20.1 \%$ & $15.7 \%$ & $15.6 \%$ \\
\hline
\end{tabular}

Note: Principle Components Factor Analysis (varimax rotation, orthogonal solution) was used to extract core factor scores, uncorrelated linear combinations of the weighted observed variables (STATA). LR test chi2 $=832.15, \mathrm{p}<.01,453$ observations, with 21 parameters. Most Government Perception scale items are rated on a scale of 1 to 5 , where (1) Strongly Disagree, (2) Disagree, (3) Neutral, (4) Agree, (5) Strongly Agree, as follows. Public Hassle: "Public programs, including the MRB program, tend to be more cumbersome and less efficient than market programs". MRB Important: "The MRB program provides an important loan product, not provided by other programs". MRB Hassle: "The hassle of the MRB program is greater than any benefit it provides." The scale item for MRB Helpful, is based on a scale of 1 to 5, where (1) Very Burdensome, (2) Somewhat Burdensome, (3) Neither Helpful or Burdensome, (4) Somewhat Helpful and (5) Very Helpful: "In general, how helpful or burdensome is the MRB program to your experience as an originating lender". Public Values scale items are rated on a scale of 1 to 5, where (1) Strongly Disagree, (2) Disagree, (3) Neutral, (4) Agree, (5) Strongly Agree. The survey item for "Low Income Borrowers" reads as follows: "Low income borrowers are an important part of my business". The survey item for "Fixed, Low Interest Rates" reads: "It is very important to provide low income borrowers fixed rate mortgages with low interest rates". The survey item for "Flexible Rates for High Risk" reads: "It very important to offer credit compromised borrowers access to homeownership through the use of flexible interest rates and financing tools". 
Table 3: Factor Loadings for Community Ties Factors

\begin{tabular}{rcc}
\hline Frequency of Contact With: & External Contact Factor & Low Public Contact Factor \\
\hline Nonprofit Organizations & 0.8222 & -0.2807 \\
Housing Organizations & 0.7405 & -0.3425 \\
Local Government & 0.8437 & -0.1226 \\
Private Builders & 0.46 & 0.7448 \\
Other Lenders & 0.6089 & 0.3217 \\
Other Private Businesses & 0.7214 & 0.0685 \\
Eigenvalue & 3.039 & 0.874 \\
Percent of Variance & $50.6 \%$ & $14.6 \%$ \\
\hline
\end{tabular}

Note: Principle Components Factor Analysis was used to extract core factor scores, uncorrelated linear combinations of the weighted observed variables, unrotated solution (STATA). LR test chi2 $=951.52, p<.01,514$ observations, with 15 parameters. Frequency of contact indicators are based on survey items, where respondents indicate frequency of contact with the listed entity, where (1) never, (2) less than yearly, (3) yearly, (4) monthly, (5) weekly, and (6) daily. 
Table 4A: Multinomial Logit Analysis of MRB Lending Volume

Lending Volume Low (<5\%); Average (5-25\%); High (25-50\%); and Very High (>50\%)

Low versus Average High versus Average

$\beta \quad \mathrm{e}^{\wedge} \beta$

$\beta$

County Income

$-2.521 \wedge 0.080$

$\beta \quad \exp \beta$

Very High versus Average

County Housing Age

County Unemployment

$-0.021 \quad 0.980$

$0.620 \quad 1.859$

$\beta \quad \exp \beta$

$-0.006 \quad 0.994$

$0.994 \quad 2.701$

$-0.072 \quad 0.930$

$-0.396$

$-0.002$

0.998

County HO Rate

$-1.011 \quad 0.364$

7.513

$-0.364$

0.673

$-0.148$

0.863

\section{Bank}

Lender Small

$0.381 \quad 1.464$

$-0.418$

1831.686

$-8.392$

0.000

$1.044 \wedge \quad 2.842$

0.667

0.695

$-0.083$

0.920

Lender Large

$1.010 * 2.744$

$-0.531$

0.659

0.805

2.237

Indiana

$0.706 \quad 2.025$

$-0.641$

1.948

$-1.074$

0.342

0.588

0.233

1.262

0.527

$-1.461$

0.232

College Degree

$-0.586 * 0.556$

$-0.072$

0.930

$-0.145$

0.865

Time Community

Time Job

$-0.014 \quad 0.986$

$-0.086$

0.918

$-0.072$

0.931

Time MRB

Low Income Factor

Low Public Factor

Low MRB Factor

High Cost Factor

$\begin{array}{ll}-0.033 & 0.967\end{array}$

$-0.001$

0.999

$-0.093 * 0.911$

$0.094 \wedge \quad 1.099$

$0.059 \quad 1.061$

$-0.459 * 0.632$

$0.754 * 2.126$

$0.678 * \quad 1.970$

$0.374 * 1.454$

$-0.289 \wedge$

0.749

$-0.524 * 0.592$

$0.431 * * \quad 1.539$

$0.014 \quad 1.014$

$-0.442 * 0.643$

$0.109 \quad 1.115$

External Contact Factor

Low Public Contact Factor

$0.033 \quad 1.033$

$0.292 \quad 1.339$

$0.196 \quad 1.216$

$0.187 \quad 1.205$

$\begin{array}{lll}-0.588 & * * & 0.555\end{array}$

Constant

$-0.317 \wedge 0.728$

$-0.471 * * \quad 0.624$

$-24.171$

Pseudo R2

$28.209 \wedge$

$-9.884$

\section{$\mathrm{N}$}

406

Note: Robust, standard errors adjusted for 99 clusters by lending institution. Dummy variables for primary lending institutions included in the model, but not shown here. See Appendix C. Reference categories for state is Florida and size is Lender Midsize. ${ }^{\wedge} \mathrm{p}<.10,{ }^{*} \mathrm{p}<.05,{ }^{* *} \mathrm{p}<.01$ 
Table 4B: Discrete Change in Probability for a Multinomial Logit Model of MRB Loan Volume.

\begin{tabular}{rrrrrrr}
\hline Variable & Change & Avg $\Delta$ & $<5 \%$ & $5-25 \%$ & $26-50 \%$ & $>50 \%$ \\
\hline \multirow{4}{*}{ Low Income Factor } & $\Delta$ Range & 0.40 & -0.80 & 0.15 & 0.18 & 0.46 \\
& $\Delta 1$ & 0.10 & -0.16 & -0.04 & 0.06 & 0.14 \\
& $\Delta \sigma$ & 0.09 & -0.15 & -0.04 & 0.05 & 0.13 \\
Low MRB Factor & $\Delta$ Range & 0.34 & 0.67 & -0.16 & -0.03 & -0.48 \\
& $\Delta 1$ & 0.06 & 0.12 & -0.01 & 0.00 & -0.11 \\
& $\Delta$ Range & 0.30 & 0.53 & 0.08 & -0.08 & -0.53 \\
& $\Delta \sigma$ & 0.07 & 0.12 & 0.02 & -0.02 & -0.12 \\
& $\Delta \sigma$ & 0.07 & 0.12 & 0.02 & -0.02 & -0.12 \\
& $\Delta$ Range & 0.07 & -0.03 & -0.10 & 0.08 & 0.05 \\
External Contact Factor & $\Delta 1$ & 0.02 & -0.01 & -0.02 & 0.02 & 0.01 \\
& $\Delta \sigma$ & 0.02 & -0.01 & -0.02 & 0.02 & 0.01 \\
& $\Delta$ Range & 0.11 & -0.15 & -0.07 & 0.05 & 0.17 \\
& $\Delta 1$ & 0.03 & -0.04 & -0.02 & 0.01 & 0.04 \\
Low Public Contact Factor & $\Delta$ Range & 0.28 & -0.02 & 0.55 & -0.08 & -0.45 \\
& $\Delta 1$ & 0.05 & -0.01 & 0.11 & -0.02 & -0.08 \\
& $\Delta \sigma$ & 0.05 & -0.01 & 0.11 & -0.02 & -0.08 \\
& & & 0.29 & 0.39 & 0.08 & 0.24 \\
\hline
\end{tabular}

Note: $\Delta$ Range is the change in predicted probability from the minimum value of $X$ to its maximum value; $\Delta 1$ is the centered change of one unit around the mean; $\Delta \sigma$ is the centered change of one standard deviation around the mean. All other model variables (including those from the full MNL model not shown here) are held at their mean (continuous) or modal (binary) values. 


\section{Appendix A: Survey Description}

\section{Survey Administration}

From August 1, 2008 to September 30, 2008 (Indiana and Ohio), and February (2009)

originating lenders participating in the MRB programs in Ohio, Indiana and Florida were contacted by the principal researcher to complete a brief survey about their experiences with the MRB program, specifically focusing on their marketing and borrower education practices ${ }^{15}$. Loan originators participating in the program and thus completing the survey were either (1) identified by the corporate contacts for the lending institutions participating in the MRB program (Ohio and Indiana), or (2) from the publicly listed originators on the HFAs website (Ohio and Florida). In Ohio and Indiana, corporate contacts (provided by the HFA's) were initially contacted for their preferences for administering the survey to their loan originators. Corporate contacts either provided the HFAs with a list of loan originators or directly dispersed the electronic survey link to their originators. In Ohio, corporate contacts could also elect to defer to the publicly available list of originator contacts on OHFA's website. Further, if the corporate contacts did not respond, the publicly available list of originator contacts was utilized for the respective lending institutions in Ohio. In Indiana, corporate contacts representing 56 participating lending institutions were initially contacted, of which 31 participating lending institutions provided originator feedback from a total of 139 originators (110 complete responses), for a response rate of 55 percent. In Ohio, corporate contacts representing 119 participating lending institutions were initially contacted, of which 60 participating lending institutions provided originator feedback from a total of 222 originators (180 complete responses), for a response rate of 51 percent. In Florida, 251 originators responded to the survey (213 complete responses), representing 48 unique lending institutions (out of 1,489 originators representing 89 lending institutions), for a response rate of $53 \%$ of lending institutions or $17 \%$ of originators.

\section{Key Survey Questions}

\section{Perceptions of Government}

Public Hassle

Indicate how strongly you agree or disagree with the following statement: Public programs, including the MRB [Program Name] program, tend to be more cumbersome and less efficient than market programs.

(1) Strongly disagree; (2) Disagree; (3) Neutral; (4) Agree; (5) Strongly agree

\section{MRB Helpful}

Now, we would like you to reflect on your experiences working with the MRB program [Program Name]. In general, how helpful or burdensome is the MRB program to your experience as an originating lender?

(1) Extremely burdensome; (2) Somewhat burdensome; (3) Neither burdensome or helpful; (4) Somewhat helpful; (5) Extremely helpful

\footnotetext{
${ }^{15}$ Originators were contacted on behalf of the HFAs in Ohio and Indiana, and on behalf of the principal researcher in Florida.
} 


\section{MRB Important}

Indicate how strongly you agree or disagree with the following statement:

The MRB [Program Name] program provides an important loan product for my borrowers, not provided by other programs.

(1) Strongly disagree; (2) Disagree; (3) Neutral; (4) Agree; (5) Strongly agree

\section{MRB Hassle}

Indicate how strongly you agree or disagree with the following statement:

The hassle of the MRB [Program Name] program is greater than any benefit it provides to homebuyers.

(1) Strongly disagree; (2) Disagree; (3) Neutral; (4) Agree; (5) Strongly agree

\section{Public Values}

Low Income Borrowers

Indicate how strongly you agree or disagree with the following statement:

Low income homebuyers are an important part of my business.

(1) Strongly disagree; (2) Disagree; (3) Neutral; (4) Agree; (5) Strongly agree

Fixed Low Interest Rates

Indicate how strongly you agree or disagree with the following statement:

It is very important to provide low income borrowers fixed rate mortgages with low interest rates.

(1) Strongly disagree; (2) Disagree; (3) Neutral; (4) Agree; (5) Strongly agree

Flexible Rates for High Risk

Indicate how strongly you agree or disagree with the following statement:

It very important to offer credit compromised borrowers access to homeownership through the use of flexible interest rates and financing tools.

(1) Strongly disagree; (2) Disagree; (3) Neutral; (4) Agree; (5) Strongly agree

\section{Community Ties}

In general, how frequently do you have contact (in person, phone or email) with the following types of individuals or organizations related to your role at the lending institution?

(1) Never; (2) Less Than Yearly; (3) Yearly; (4) Monthly; (5) Weekly; (6) Daily

Nonprofit Organizations

Housing Counselors

Local Government

Private Builders

Other Lenders

Other Private Businesses 
Appendix B: Correlation Matrix for Dependent and Key Independent Variables

\begin{tabular}{|c|c|c|c|c|c|c|c|c|c|c|c|c|c|c|c|}
\hline & & 1 & 2 & 3 & 4 & 5 & 6 & 7 & 8 & 9 & 10 & 11 & 12 & 13 & 14 \\
\hline 1 & MRB Loan Volume & 1.00 & 0.26 & 0.18 & -0.25 & -0.18 & 0.30 & 0.21 & & 0.14 & 0.18 & 0.18 & & & 0.09 \\
\hline 2 & MRB Helpful & 0.26 & 1.00 & 0.38 & 0.34 & -0.43 & 0.32 & 0.25 & 0.21 & 0.17 & 0.17 & 0.18 & & & 0.10 \\
\hline 3 & MRB Important & 0.18 & 0.38 & 1.00 & -0.32 & -0.09 & 0.51 & 0.60 & 0.34 & & & 0.10 & & & \\
\hline 4 & MRB Hassle & -0.25 & 0.34 & -0.32 & 1.00 & 0.35 & -0.13 & -0.15 & -0.11 & & & & & & \\
\hline 5 & Public Hassle & -0.18 & -0.43 & -0.09 & 0.35 & 1.00 & & & & & & & & & \\
\hline 6 & Low Income Borrowers & 0.30 & 0.32 & 0.51 & -0.13 & & 1.00 & 0.59 & 0.39 & 0.22 & 0.15 & 0.21 & & & \\
\hline 7 & Fixed Low Interest Rates & 0.21 & 0.25 & 0.60 & -0.15 & & 0.59 & 1.00 & 0.42 & 0.11 & & 0.16 & & 0.13 & \\
\hline 8 & Flexible Rates for High Risk & & 0.21 & 0.34 & -0.11 & & 0.39 & 0.42 & 1.00 & & & & & & \\
\hline 9 & Nonprofit Organizations & 0.14 & 0.17 & & & & 0.22 & 0.11 & & 1.00 & 0.62 & 0.66 & 0.25 & 0.34 & 0.49 \\
\hline 10 & Housing Organizations & 0.18 & 0.17 & & & & 0.15 & & & 0.62 & 1.00 & 0.56 & 0.24 & 0.28 & 0.36 \\
\hline 11 & Local Government & 0.18 & 0.18 & 0.10 & & & 0.21 & 0.16 & & 0.64 & 0.56 & 1.00 & 0.29 & 0.46 & 0.54 \\
\hline 12 & Private Builders & & & & & & & & & 0.25 & 0.24 & 0.29 & 1.00 & 0.23 & 0.25 \\
\hline 13 & Other Lenders & & & & & & & 0.13 & & 0.34 & 0.28 & 0.46 & 0.23 & 1.00 & 0.41 \\
\hline 14 & Other Private Businesses & 0.09 & 0.10 & & & & & & & 0.49 & 0.36 & 0.53 & 0.25 & 0.41 & 1.00 \\
\hline
\end{tabular}

Note: Only those correlations that are statistically significant at $p<.05$ are shown here. 
Appendix C: Multinomial Logit Analysis of MRB Lending Volume

\begin{tabular}{|c|c|c|c|c|c|c|c|c|c|}
\hline & \multicolumn{3}{|c|}{ Low versus Average } & \multicolumn{3}{|c|}{ High versus Average } & \multicolumn{3}{|c|}{ Very High versus Average } \\
\hline & $\beta$ & & $\mathrm{e}^{\wedge} \beta$ & $\beta$ & & $\exp \beta$ & $\beta$ & & $\exp \beta$ \\
\hline County Income & -2.521 & $\wedge$ & 0.080 & 0.620 & & 1.859 & 0.994 & & 2.701 \\
\hline County Housing Age & -0.021 & & 0.980 & -0.006 & & 0.994 & -0.002 & & 0.998 \\
\hline County Unemployment & -0.072 & & 0.930 & -0.396 & $\wedge$ & 0.673 & -0.148 & & 0.863 \\
\hline County HO Rate & -1.011 & & 0.364 & 7.513 & & 1831.686 & -8.392 & & 0.000 \\
\hline Bank & 0.381 & & 1.464 & -0.364 & & 0.695 & -0.083 & & 0.920 \\
\hline Lender Small & 1.044 & $\wedge$ & 2.842 & -0.418 & & 0.659 & 0.805 & & 2.237 \\
\hline Lender Large & 1.010 & $*$ & 2.744 & 0.667 & & 1.948 & -1.074 & & 0.342 \\
\hline Indiana & 0.706 & & 2.025 & -0.531 & & 0.588 & 0.233 & & 1.262 \\
\hline Ohio & 0.572 & & 1.772 & -0.641 & & 0.527 & -1.461 & & 0.232 \\
\hline College Degree & -0.586 & $*$ & 0.556 & -0.072 & & 0.930 & -0.145 & & 0.865 \\
\hline Time Community & -0.014 & & 0.986 & -0.086 & * & 0.918 & -0.072 & & 0.931 \\
\hline Time Job & -0.033 & & 0.967 & -0.001 & & 0.999 & -0.093 & $*$ & 0.911 \\
\hline Time MRB & -0.068 & & 0.934 & 0.094 & $\wedge$ & 1.099 & 0.059 & & 1.061 \\
\hline Low Income Factor & -0.459 & $*$ & 0.632 & 0.754 & $*$ & 2.126 & 0.678 & $*$ & 1.970 \\
\hline Public Factor & 0.374 & $*$ & 1.454 & -0.289 & $\wedge$ & 0.749 & -0.524 & $*$ & 0.592 \\
\hline MRB Factor & 0.431 & ** & 1.539 & 0.014 & & 1.014 & -0.442 & $*$ & 0.643 \\
\hline High Cost Factor & 0.033 & & 1.033 & 0.292 & & 1.339 & 0.109 & & 1.115 \\
\hline External Contact Factor & -0.085 & & 0.919 & 0.187 & & 1.205 & 0.196 & & 1.216 \\
\hline Low Public Contact Factor & -0.317 & $\wedge$ & 0.728 & -0.471 & $* *$ & 0.624 & -0.588 & $* *$ & 0.555 \\
\hline Lender 1 & -0.854 & $\wedge$ & 0.426 & 0.443 & & 1.557 & -0.470 & & 0.625 \\
\hline Lender 2 & 0.333 & & 1.396 & 0.619 & & 1.857 & -38.645 & $* *$ & 0.000 \\
\hline Lender 3 & -1.544 & $* *$ & 0.214 & 1.507 & $*$ & 4.512 & -38.352 & $* *$ & 0.000 \\
\hline Lender 4 & 0.998 & $\wedge$ & 2.713 & 0.810 & $\wedge$ & 2.247 & 1.228 & & 3.414 \\
\hline Lender 5 & -1.585 & $* *$ & 0.205 & 0.166 & & 1.180 & -1.040 & & 0.354 \\
\hline Lender 6 & -0.163 & & 0.850 & -0.754 & $\wedge$ & 0.471 & -1.688 & $*$ & 0.185 \\
\hline Lender 7 & 1.547 & $*$ & 4.697 & -37.844 & $* *$ & 0.000 & -39.146 & $* *$ & 0.000 \\
\hline Lender 8 & -0.393 & & 0.675 & -38.319 & $* *$ & 0.000 & 1.077 & & 2.936 \\
\hline Lender 9 & -1.090 & $*$ & 0.336 & 0.041 & & 1.042 & -2.382 & $* *$ & 0.092 \\
\hline Lender 10 & -1.192 & $\wedge$ & 0.304 & -37.856 & $* *$ & 0.000 & 1.557 & & 4.745 \\
\hline Lender 11 & -0.337 & & 0.714 & 2.834 & $* *$ & 17.011 & 1.320 & $\wedge$ & 3.742 \\
\hline Lender 12 & -1.851 & $* *$ & 0.157 & -36.946 & $* *$ & 0.000 & -38.255 & $* *$ & 0.000 \\
\hline Lender 13 & 0.762 & & 2.142 & -0.619 & & 0.538 & -38.537 & $* *$ & 0.000 \\
\hline Lender 14 & -0.585 & & 0.557 & 0.382 & & 1.466 & -39.656 & $* *$ & 0.000 \\
\hline Lender 15 & -1.090 & $*$ & 0.336 & -0.639 & & 0.528 & -2.521 & $* *$ & 0.080 \\
\hline Lender 16 & -39.684 & $* *$ & 0.000 & -0.366 & & 0.694 & 3.252 & $*$ & 25.853 \\
\hline Lender 17 & -37.455 & $* *$ & 0.000 & 1.267 & $*$ & 3.551 & 1.017 & & 2.765 \\
\hline Lender 18 & -38.371 & $* *$ & 0.000 & 1.818 & $* *$ & 6.157 & 1.813 & & 6.129 \\
\hline Lender 19 & -0.082 & & 0.922 & 0.842 & & 2.321 & -0.030 & & 0.971 \\
\hline Constant & 28.209 & $\wedge$ & & -9.884 & & & -24.171 & & \\
\hline
\end{tabular}

$\mathrm{N}=406$; Pseudo $\mathrm{R} 2=0.231^{* * ;}{ }^{\wedge} \mathrm{p}<.10,{ }^{*} \mathrm{p}<.05,{ }^{* *} \mathrm{p}<.01$

Note: Robust, standard errors adjusted for 99 clusters by lending institution.

Low (<5\%); Average (5-25\%); High (25-50\%); Very High ( $>50 \%)$ 


\section{References}

Agarwal, S. 1993. Influence of Formalization on Role Stress, Organizational Commitment, and Work Alienation of Salespersons: A Cross-National Comparative Study. Journal of International Business Studies 24(4): 715-739.

Aguilera, Ruth V, Rupp Deborah, Williams Cynthia A, and Jyoti Ganapathi. 2007. Putting the $\mathrm{S}$ back in corporate social responsibility: A multilevel theory of social change in organizations. Academy of Management Review, 32(3), 836-63.

Alexander, William P., Scott D. Grimshaw, Grant R. McQueen and Barrett A. Slade. 2002. Some Loans are More Equal than Others: Third Party Originators and Defaults in the Subprime Mortgage Industry. Real Estate Economics 30(4): 66797.

Antonsen, Marianne, and Torben B. Jorgensen. 1997. The 'Publicness' of Public Organizations. Public Administration 75: 337-57.

Avery, Robert B., P.E. Beeson, and M.S. Sniderman. 1994. Cross-Lender Variation in Home Mortgage Lending. Federal Reserve Bank of Cleveland Economic Review 30:15-29.

Bozeman, Barry. 1987. All organizations are public. San Francisco: Jossey-Bass.

Bozeman, Barry. 2007. Public Values and Public Interest: Counterbalancing Economic Individualism. Washington, DC: Georgetown University Press.

Bozeman, Barry, \& Bretschneider, Stu. 1994. The "Publicness Puzzle" in Organization Theory: A Test of Alternative Explanations of Differences between Public and Private Organizations. Journal of Public Administration Research And Theory, 4(2), 197-223.

Boyne, George, Brewer, Gene. A., \& Walker, Richard. 2006. Strategy, Red Tape, and Organizational Performance: An Empirical Odyssey. Paper presented at A Performing Public Sector: The Second TransAtlantic Dialogue, Katholieke Universiteit, Leuven, Belgium, 1-3 June 2006.

Brewer, Gene. A., Selden, Sally C., \& Facer, R. L. 2000. Individual conceptions of public service motivation. Public Administration Review, 60(3), 254-264.

Brewer, Gene A., \& Walker, Richard. 2006. Can Managers Reduce Red Tape? An Empirical Analysis of Environmental Constraints and Internal Management. Prepared for delivery at the 2006 Annual Meeting of the American Political Science Association, Philadelphia Marriott, Loews Philadelphia, and Pennsylvania Convention Center, Philadelphia, Pennsylvania, August 31 - September 3. 
Buckley, P. and M. Chapman. 1997. The perception and measurement of transaction costs. Cambridge Journal of Economics 21:127-145.

Burt, Ronald S. 1992. Structural Holes: The social structure of Competition. Cambridge, MA: Harvard University Press.

Coursey, David H., \& Pandey, Sanjay K. 2007. Public Service Motivation Measurement: Testing an Abridged Version of Perry's Proposed Scale. Administration \& Society, 39(5), 547568.

Ding, Lei, Roberto Quercia, Janneke Ratcliffe and Wei Li. 2008. Risky Borrowers or Risky Mortgages: Disaggregating Effects Using Propensity Score Models. Center for Community Capital, Working Paper. October.

Emmert, M. and Michael Crow. 1988. Public, Private and Hybrid Organizations: An Empirical Examination of the Role of Publicness. Administration and Society 20: 216-44.

Feeney, Mary Kathleen, and Barry Bozeman. 2007. Public Values and Public Failure Implications of the 2004-2005 Flu Vaccine Case Public Integrity 9 (2):175-190.

Fishbein, Allen J. 1992. The ongoing experiment with "regulation from below": Expanded reporting requirements for HMDA and CRA. Housing Policy Debate. 3(2): 601-36.

Francois, Patrick and Michael Vlassopoulos. 2008, Pro-social motivation and the delivery of social services," CESifo Economic Studies, 54(1), 22-54.

Gabris, Gerald T., and Gloria Simo. 1995. Public Sector Motivation as an Independent Variable Affecting Career Decisions. Public Personnel Management, 24(1): 33-51.

Goodsell, Charles. 2004. The Case for Bureaucracy: A Public Administration Polemic. $4^{\text {th }}$ Edition. Washington DC: CQ Press.

Granovetter, Mark. 1973. The strength of weak ties. American Journal of Sociology. 78:1360-80.

Heinrich, Carolyn. J. and Elizabeth Fournier. 2004. Dimensions of Publicness and

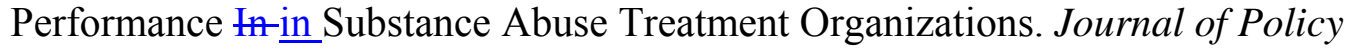
Analysis and Management 23(1): 49-70.

Holyoke, Thomas T. 2004. Community Mobilization and Credit: The Impact of Nonprofits and Social Capital on Community Reinvestment Lending. Social Science Quarterly 85(1): 187-205.

Immergluck, Dan. 2008. Out of the Goodness of their Hearts? Regulatory and Regional Impacts on Bank Investment in Housing and Community Development in the United States. Journal of Urban Affairs 30(1): 1-20. 
Ladd, Helen F. 1998. Evidence on discrimination in mortgage lending. The Journal of Economic Perspectives. 12(2): 41-62.

Lipsky, Micheal. 1980. Street Level Bureaucracy: Dilemmas of the Individual in Public Services. New York: Russell Sage Foundation.

Long, J. Scott and Jeremy Freese. 2006. Regression Models for Categorical Dependent Variables Using Stata, 2nd Edition. College Station: Stata Press.

Long, J. Scott. 1997. Regression models for categorical and limited dependent variables. Thousand Oaks, CA: Sage Publications.

Maynard-Moody, Steven, and Michael Musheno. 2000. State Agent or Citizen Agent: Two Narratives of Discretion Journal of Public Administration Research and Theory, 10 (2)L329-358.

Maynard-Moody, Steven, and Michael Musheno. 2003. Organizational and Social Divisions among Street-Level Workers in Cops, Teachers, Counselors: Stories from the Front Lines of Public Service. Chapter 6: pp. 64-76.

Moulton, Stephanie. 2009. Putting Together the Publicness Puzzle: A Framework for Realized Publicness. Public Administration Review. Forthcoming

Moynihan, Donald P., \& Pandey, Sanjay. K. 2007. The Role of Organizations in Fostering Public Service Motivation. Public Administration Review.

Naff, Katherine C., and John Crum. 1999. Working for America: does public service motivation make a difference? Review of Public Personnel Administration 19(4): 5-16.

NCSHA National Council of State Housing Finance Agencies. 2008. The 2008 Housing Bonds Program Fact Sheet. -Published online at: http://www.homemeanseverything.org/assets/HousingBondsFactSheet2009.pdf

O’Connor, Robert E., Bord, Richard J., and Fisher, Ann. 1999. Risk perceptions, general environmental beliefs, and willingness to address climate change. Risk Analysis 19(3): 461-471.

| Pandey, Sanjay K., \&and Welch, Eric W. 2005. Beyond Stereotypes: A Multistage Model of Managerial Perceptions of Red Tape. Administration \& Society, 37(5), 542.

Perry, James L, and Lois R. Wise. 1990. The Motivational Bases of Public Service. Public Administration Review 50(3), 367-73. 
Perry, James L. 1996. Measuring Public Service Motivation: An Assessment of Construct Reliability and Validity. Journal of Public Administration Research and Theory $\underline{6(1), 5-22 .}$

Poppo, Laura, and Ted Zenger. 2002. Do Formal Contracts and Relational Governance Function as Substitutes or Complements? Strategic Management Journal, 23(8):707-725.

Powell, W.W. 1990. Neither market nor hierarchy: Network forms of organization. In L.L. Cummings \& B. Shaw (Eds.), Research in organizational behavior (vol. 12, pp. 235-336). Greenwich, CT: JAI Press.

Rosenfeld, R. A. 1984. An Expansion and Application of Kaufman's Model of Red Tape: The Case of Community Development Block Grants. The Western Political Quarterly, 37(4), 603-620.

Scott, Richard. 2003. Institutional Carriers: Reviewing Modes of Transporting Ideas over Time and Space and Considering Their Consequences. Industrial and Corporate Change 12(4): 879-894.

Scott, Patrick G., \& Pandey, Sanjay K. 2005. Red Tape and Public Service Motivation: Findings from a National Survey of Managers in State Health and Human Services Agencies. Review of Public Personnel Administration, 25(2), 155-180.

Scott, Patrick G. and Santa Falcone. 1998. Comparing Public and Private Organizations: An Exploratory Analysis of Three Frameworks. The American Review of Public Administration 28(2) 126-45.

Steijn, Bram \& Peter Smulders. 2004. Work values and work experiences in the Dutch public and private sector. Paper for the European Group of Public Administration, September. Llubljana, Slovakia.

Taylor, Jeannette. 2008. Organizational Influences, Public Service Motivation and Work Outcomes, International Public Management Journal, 11, 1, 67-88.

Uzzi, Brian. 1999. Embeddedness in the making of financial capital: How social relations and networks benefit firms seeking financing. American Sociological Review. 64(4): 481-505.

Van der Wal, Zeger, G. de Graaf, and K. Lasthuizen. 2008. What's valued most? Similarities and differences between the organizational values of the public and private sector. Public Administration, 86(2):465-482.

Weber, Max. 1904/05. The Protestant Ethic and the Spirit of Capitalism (Die protestantische Ethik und der Geist des Kapitalismus). Translated by Peter Baehr and Gordon C. Wells. (Penguin Books, 2002). 
Wittmer, D. 1991. Serving the People or Serving For Pay: A Comparative Study of Values and Reward Preferences Among Managers in Government, Business and Hybrid Organizations. Public Productivity and Management Review 14:369-383. 